\title{
EFFECT Of SOME LeVELS from NIGella SATIVA AS SEedS OR WATER EXTRACT ON RATS SUFFERING FROM HyperLIPIDEMIa ANo DiabeTES.
}

\author{
By \\ Mona Massoud El-Said \\ Nutrition and Food Science Dept. \\ Faculty of Home Economics, Helwan University, Egypt.
}

\section{Research Joupnal Specific Education \\ Faculty of Specific Education \\ Mansoura University}

ISSUE NO. 25, APRIL. 2012

مجلة بحوث التربية النوعية - جامعة المنصورة

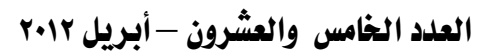


ב Effect of Some Levels from Nigella Sativa as Seeds or Water Extract on Rats Suffering 


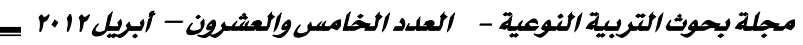

\title{
EfFect Of SOME LeVElS from Nigella SATIVA AS SeEDS OR WATER EXTRACT ON RATS SUFFERING FROM HYPERLIPIDEMIA and Diabetes.
}

\author{
Mona Massoud El-Said *
}

Abstract

Objective: The main target of this study was to investigate the effect of diets supplemented with three levels from Nigella sativa seeds $(2.5,5$ and $10 \%$ ) or water extract of Nigella sativa seeds in drinking water $(2.5 \%, 5 \%$ and $10 \% \mathrm{~W} / \mathrm{V})$ on serum glucose, lipid profile, kidney functions and liver enzymes in addition to nutrition evaluation of rats suffering from hyperlipidemia and diabetes.

Material \& Methods: The experiment was carried out using 48 male albino rats (Sprague Dawley strain) weighting $130 \pm 5 \mathrm{~g}$. The rats were divided into two main groups. The first main group $(n=6)$ fed on basal diet as negative control. The second main group $(n=42)$ fed on hyperlipidimic diet for 6 week to induce hyperlipidemia, after this period, the second main group injected with $(150 \mathrm{mg}$ aloxane / $\mathrm{kg}$ body weight) to induce hyperglycemia. The rats in the second main group were randomly divided into seven subgroups as a following: Subgroup (1) fed on hyperlipidemic diet as a positive control group. Subgroups (2, 3 and 4) fed on hyperlipidemic diet containing 2.5\%, $5 \%$ and 10\% Nigella sativa seeds, respectively. Subgroups (5, 6 and 7) fed on hyperlipidemic diet and treated daily with extract of Nigella sativa seeds in drinking water $(2.5 \%, 5 \%$ and $10 \% \mathrm{~W} / \mathrm{V})$, respectively. All groups were kept feeding on experimental diets for 28 days.

Results: The results indicated that, hyperlipidemia and hyperglycemia increased serum glucose, kidney functions, liver enzymes and lipid profile, significantly, except HDL-c., as compared to healthy rats. Treating rats which were suffering from hyperlipidemia and hyperglycemia with different levels from Nigella sativa seeds or water extract prepared from different levels from Nigella sativa led to a

\footnotetext{
* Nutrition and Food Science Dept. Faculty of Home Economics, Helwan University, Egypt.
} 
general improvement in health of rats, especially when used high level from seeds or water extract.

Conclusion: It was finally concluded that, treated rats which suffer from hyperlipidemia and hyperglycemia with Nigella sativa seeds or water extract prepared from Nigella sativa seeds, especially when used high levels from seeds or extraction, could be implemented in the treatment of hyperlipidemic subjects suffering from diabetes.

Key words: Hyperlipidemia, diabetes, rats, Nigella sativa, glucose, lipid profiles, kidney functions and liver enzymes. 


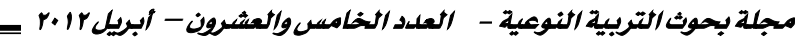

\title{
Effect of SOMe LeVels from Nigella Sativa as Seeds or WATER EXTRACT ON RATS SUFFERING FROM HYPERLIPIDEMIA aNd DIABETES.
}

\author{
Mona Massoud El-Said*
}

\section{Introduction:}

Hyperlipidemia, being an important risk factor for cardiovascular disease, is a serious public health problem in the world. Its major role in the pathogenesis of atherosclerosis has been implicated by several clinical and epidemiological studies (Jaffar et al., 2004). Hyperlipidemia also has an indirect role by stimulating the production of oxygen free radicals (OFRs) from polymorphonuclear leukocytes (PMNLs) and monocytes (Prasad, 2005). Regarding its treatment, nowadays there is an increasing interest toward the potential health benefits of medicinal plants.

Diabetes Mellitus (DM) is one of the most common metabolic disorders, with a worldwide prevalence estimated to be between $1 \%$ and $5 \%$. The increasing prevalence of DM in the world is a cause for concern. DM leads to abnormalities in carbohydrate, protein and lipid metabolism and increases the risk of developing atherosclerotic arterial disease by two- to six folds (Sacks, 1997).

Interest in medicinal plants has burgeoned due to increased efficiency of new plant- derived drugs and the growing interest in natural products. Because of the concerns about the side effects of conventional medicine, the use of natural products as an alternative to conventional treatment in healing and treatment of various diseases has been on the rise in the last few decades (Dattner, 2003 and Fong, 2002).

The use of alternative medicine (AM) has increased recently and attracted the attention of many researchers all over the world. This interest has been accentuated by a concern that such treatment may be harmful to the patients despite their apparent innocuousness (Hunt et al., 2000).

Nigella sativa Linn ( $N$. sativa) commonly known as black seed or black cumin, is an annual herb from the botanical family of Ranunculaceae. The seeds of the plant have been used in the Southeast Asia, Middle and Far East

\footnotetext{
* Nutrition and Food Science Dept. Faculty of Home Economics, Helwan University, Egypt.
} 
as a natural remedy to treat many diseases, including asthma, hypertension, diabetes, hypercholesterolemia, inflammation, arthritis, tumor, gastrointestinal disturbances and gynecological disorders for over 2000 years (Ali and Blunden, 2003; El-Din et al., 2006; Ramadan, 2007). They are extensively used as spice, condiment and aromatic which can be added to tea, coffee, casseroles or breads. The ground seed can be mixed with honey or sprinkled on salads (Ramadan, 2007).

The seed of $N$. sativa has over 100 different chemical components, including mucilage, crude fiber, reducing sugars, resins, alkaloids, flavonoids, organic acids, sterols, tannins and saponins, in addition to the high content of unsaturated fatty acids, especially linoleic acid (18:2 $\square-6)$ and oleic acid (18:1 $\square-9)$ and proteins. It also has yellowish volatile (essential) oil (Akram, 1999 and Gilani et al., 2004). It is known that the biological activity of $N$. sativa seeds is attributed to its essential oil components (Hajhashemi et al., 2004). The main compounds contained are thymoquinone $(30-48 \%)$, p-cymene $(7-15 \%)$, carvacrol $(6-12 \%)$, 4terpineol $(2-7 \%)$, t-anethole $(1-4 \%)$ and a sesquiterpene longifolene (1 8\%) (Burits and Bucar, 2000) in which thymoquinone (TQ) and its derivatives [dithymoquinone (DTQ), thymohydroquinone (THQ) and thymol (THY)] are the most putative pharmacologically active constituents of $N$. sativa (Padhye et al., 2008).

The main target of the present investigation is to study the influence of Nigella Sativa L as a Seeds or water extract on serum glucose, lipid profile, kidney functions and liver enzymes of rats suffering from hyperlipidemia and diabetes.

\section{Materials and Methods:}

\section{Materials:}

Casein, all minerals, vitamins, cellulose, choline chloride and alloxan were obtained from El-Gomhoria Company, Cairo, Egypt.

Nigella Sativa Linn (seeds) was purchased from Field Crops Research Institute, Agricultural Research Centre, Ministry of Agriculture Cairo, Egypt.

Normal male albino rats (48) Sprague Dawley Strain weighing (130 $\pm 5 \mathrm{~g})$ obtained from Helwan farm, Cairo, Egypt.

Corn oil, corn starch and vegetable ghee were obtained from local market. 


\section{Methods:}

\section{Preparation of Extract}

An extract of $N$. sativa L. seeds was prepared using the method described by Farida et al. (1987). Briefly, $N$. sativa L. seeds were purchased from a local herb store. An extract of $N$. sativa $\mathrm{L}$. seeds in drinking water $(5 \%)$ was prepared fresh daily by boiling the seeds $(50 \mathrm{~g})$ in drinking water $(1000 \mathrm{ml})$ for $10 \mathrm{~min}$ and then filtering through 4 layers of surgical gauze to obtain the water extract used for the experiment.

In this study, extractions of $N$. sativa L. seeds were prepared by using $2.5 \%$, $5 \%$ and $10 \%$.

\section{Biological Study:}

Male albino Sprague Dawley rats (48 rats weighed $130 \pm 5 \mathrm{~g}$ ) were housed in wire cages in a room maintained at $25 \pm 2^{\circ} \mathrm{C}$ in the animal house of the Faculty of Home Economics, Helwan University . The animals were kept under normal healthy conditions and fed basal diet for one week (adaptation period). The basal diet consisted of protein 14\% (as casein), corn oil $4 \%$, choline chloride $0.2 \%$, vitamin mixture $1 \%$, salt mixture $3.5 \%$, fiber $5 \%$ and the remainder was corn starch (Reeves et al., 1993), water was provided ad libitum. After the adaptation period, the rats were divided into two main groups. The first group $(\mathrm{n}=6)$ was fed basal diet as negative control (healthy rats). The second main group $(\mathrm{n}=42)$ fed on diet containing (casein 14\%; Choline chloride $0.20 \%$; vitamin mixture $1.0 \%$; salt mixture $3.5 \%$; fibers 5\%; L-Cystine $0.18 \%$, sucrose $10 \%, 20 \%$ fat (19\% saturated fat $+1 \%$ unsaturated fat), bile salts $(0.25 \%)$ and the reminder was corn starch. to induced hyperlipidemia in rats as described by (Cara et al., 1991), after this period, lipid fractions were determined in normal and hyperlipidemic groups to insure the induction of hyperlipidemia, then the second main group was injected with aloxane $(150 \mathrm{mg} / \mathrm{kg}$ body weight) to induce hyperglycemia after fasting overnight (Buko et al., 1996). The second main group was randomly divided into seven subgroups according to the following:

- Subgroup one: Fed on hyperlipidemic diet (positive control).

- Subgroup two: Fed on hyperlipidemic diet containing 2.5\% Nigella Sativa seeds.

- Subgroup three: Fed on hyperlipidemic diet containing 5\% Nigella Sativa seeds. 
- Subgroup four: Fed on hyperlipidemic diet containing 10\% Nigella Sativa seeds.

- Subgroup five: Fed on hyperlipidemic diet, and treated daily with extract of $N$. sativa $\mathrm{L}$. seeds in drinking water $(2.5 \% \mathrm{~W} / \mathrm{V}) 25 \mathrm{~g}$ Nigella Sativa seeds/ $1000 \mathrm{ml}$ water.

- Subgroup six: Fed on hyperlipidemic diet, and treated daily with extract of $N$. sativa L. seeds in drinking water $(5 \% \mathrm{~W} / \mathrm{V}) 50 \mathrm{~g}$ Nigella Sativa seeds/ $1000 \mathrm{ml}$ water.

- Subgroup seven: Fed on hyperlipidemic diet, and treated daily with extract of $N$. sativa $\mathrm{L}$. seeds in drinking water $(10 \% \mathrm{~W} / \mathrm{V}) 100 \mathrm{~g}$ Nigella Sativa seeds/ $1000 \mathrm{ml}$ water.

During the experimental period (28 days), the diets consumed and body weights were recorded twice weekly. Biological evaluation for different groups was carried out by determination of food intake, body weight gain $\%$ (BWG \%) and kidney weight/body weight\% according to Chapman et al., (1959).

At the end of the experiment, the rats were fasted overnight, and then the rats were anaesthetized and sacrificed. Blood samples were collected from the aorta. The blood samples were centrifuged and serum was separated to estimate some biochemical parameters, i.e. serum glucose according to (Tinder 1959) total cholesterol (Allain et al, 1974), triglycerides (Fossati and prenape, 1982), high-density lipoprotein cholesterol (HDL-C) (LopesVirella et al., 1977). While serum low-density lipoprotein cholesterol (LDLC) and very low- density lipoprotein cholesterol (VLDL-C) were calculated according to the equation of Friedwald et al. (1972). Serum samples were also used for determination of alanine aminotransferase (ALT) and aspartate aminotransferase (AST) activities (Reitman and Frankel 1957), Uric acid (Fosssati et al., 1980), urea nitrogen (Patton and Crouch, 1977) and creatinine (Henry, 1974).

The data obtained was analyzed statistically for standard deviation and oneway ANOVA test (Steel and Torri, 1980). 


\section{Results And disscusion:}

Effect of Some Levels from Nigella Sativa as Seeds or Water Extract on Food Intake, Body Weight Gain \% and Liver weight /body weight\% of Rats Suffering from Hyperlipidemia and Diabetes.

The effect of different levels from Nigella sativa seeds and water extract prepared from some levels from these seeds on food intake (g/day), body weight gain $\%$ and liver weight / body weight $\%$ of rats suffering from hyperlipidemia and diabetes presented in table (1).

The mean value of food intake ( $\mathrm{g} / \mathrm{day} / \mathrm{each}$ rat) of the control positive group decreased than that of the negative control group (12.323 vs. 15.633g), respectively. Food intake of all treated groups with the different levels of seeds or water extract increased, than that of the positive control group.

The highest increase in the mean value of food intake recorded for the group which treated with water extract of Nigella sativa seeds $(50 \mathrm{~g}$ seeds $/ 1000 \mathrm{ml}$ water), followed by the group treated with water extract of Nigella sativa seeds ( $100 \mathrm{~g}$ seeds $/ 1000 \mathrm{ml}$ water), respectively.

Body weight gain $\%$ of rats suffering from hyperlipidemia and hyperglycemia (control positive group) decreased significantly $p<0.05$, as compared to healthy rats (control negative group). The mean values of body weight gain $\%$ of the groups treated with low levels from Nigella sativa seeds or water extract showed non-significant changes, while the other treated groups recorded significant increase $p<0.05$, as compared to the positive control group.

Data presented in this table revealed that, non-significant difference in body weight gain $\%$ was observed in the groups treated with medium and high levels from Nigella sativa seeds or water extract, as compared to the negative control group.

The mean value of liver weight / body weight $\%$ increased significantly in the positive control group, as compared to the negative control group. All treated groups which were suffering from hyperlipidemia and diabetes with the three levels from (Nigella sativa seeds or water extract) showed significant decrease, as compared to the positive control group, except group of rats which treated with hyperlipidemic diet containing $2.5 \%$ Nigella sativa seeds. 
The highest decrease in the percent of this organ recorded for the groups treated with water extract prepared from of $(10 \%$ and $5 \% \mathrm{~N}$. sativa), respectively.

Table (1): Effect of Some Levels from Nigella Sativa as a Seeds or Water Extract on Food Intake, Body Weight Gain \% and Liver weight /body weight $\%$ of Rats Suffering from Hyperlipidemia and Diabetes.

\begin{tabular}{|c|c|c|c|}
\hline Groups $\quad$ Parameters & $\begin{array}{l}\text { Food Intake } \\
\text { (g/day/rat) }\end{array}$ & $\begin{array}{c}\text { Body } \\
\text { weight \% }\end{array}$ & $\begin{array}{l}\text { Liver weight / } \\
\text { body weight \% }\end{array}$ \\
\hline Control (-ve) & 15.633 & $\begin{array}{l}38.6566^{\mathrm{a}} \\
\pm 1.981\end{array}$ & $\begin{array}{l}3.008^{d e} \\
\pm 0.190\end{array}$ \\
\hline Control (+ve) & 12.323 & $\begin{array}{l}31.609^{\mathrm{c}} \\
\pm 1.512\end{array}$ & $\begin{array}{l}3.934^{\mathrm{a}} \\
\pm 0.172\end{array}$ \\
\hline $2.5 \%$ N. sativa seed & 13.551 & $\begin{array}{l}33.552^{\mathrm{c}} \\
\pm 1.636\end{array}$ & $\begin{array}{l}3.817^{\mathrm{ab}} \\
\pm 0.198\end{array}$ \\
\hline $5 \%$ N. sativa seed & 13.860 & $\begin{array}{l}36.588^{a b} \\
\pm 2.128\end{array}$ & $\begin{array}{l}\mathbf{3 . 5 5 6}^{\mathrm{bc}} \\
\pm 0.132\end{array}$ \\
\hline $10 \%$ N. sativa seed & 13.800 & $\begin{array}{l}37.065^{a} \\
\pm 2.243\end{array}$ & $\begin{array}{l}3.286^{\mathrm{cd}} \\
\pm 0.079\end{array}$ \\
\hline $\begin{array}{l}\text { Water extract of } N . \text { sativa } \\
(2.5 \%)\end{array}$ & 13.692 & $\begin{array}{l}\mathbf{3 4 . 0 0 6}^{\mathrm{bc}} \\
\pm 1.931\end{array}$ & $\begin{array}{l}3.527^{\mathrm{bc}} \\
\pm 0.411\end{array}$ \\
\hline $\begin{array}{l}\text { Water extract of } N . \text { sativa } \\
(5 \%)\end{array}$ & 14.210 & $\begin{array}{l}37.673^{a} \\
\pm 2.437\end{array}$ & $\begin{array}{l}3.096^{\text {de }} \\
\pm 0.375\end{array}$ \\
\hline $\begin{array}{l}\text { Water extract of } N . \text { sativa } \\
(10 \%)\end{array}$ & 14.00 & $\begin{array}{l}38.166^{a} \\
\pm 3.166\end{array}$ & $\begin{array}{l}2.851^{\mathrm{e}} \\
\pm 0.437\end{array}$ \\
\hline
\end{tabular}

LSD: Least significant differences $(P<0.05) \quad$ Mean values in each column with same letters are not significantly different.

Effect of Some Levels from Nigella Sativa as Seeds or Water Extract on Lipid Profile of Rats Suffering from Hyperlipidemia and Diabetes.

Finding in tables (2) presented the effect of Nigella sativa as a seeds or water extract on total cholesterol, triglycerides, high density lipoprotein (HDL-c), low and very low density lipoprotein (LDL-c and VLDL-c) of serum rats suffering from hyperlipidemia and diabetes. 
مجلة بحوث التربية النوعية - العلد الخامسوالعشرون - أبريل r ا.r |

The mean values of serum cholesterol, triglycerides, LDL-c and VLDL-c $(\mathrm{mg} / \mathrm{dl})$ increased significantly at $\mathrm{p}<0.05$, whereas, the mean value of serum HDL-c decreased significantly in the positive control group in comparison with the negative control group.

Feeding rats, which were, suffer from hyperlipidemia and diabetes on hyperlipidemic diet containing $(2.5 \%, 5 \%$ and $10 \%$ Nigella sativa) or feeding rats on hyperlipidemic diet and treating with water extract prepared from $2.5 \%, 5 \%$ and $10 \%$ Nigella sativa (W/V) enhanced the mean values of serum lipid fractions, particularly, with high level of seeds or water extract.

Table (2): Effect of Some Levels from Nigella Sativa as a Seeds or Water Extract on Lipid Profile of Rats Suffering from Hyperlipidemia and Diabetes.

\begin{tabular}{|c|c|c|c|c|c|}
\hline \multirow{2}{*}{$\left.\right|_{\text {Groups }}$ Parameters } & \multicolumn{5}{|c|}{$\mathrm{mg} / \mathrm{dl}$} \\
\hline & Ch. & TG & HDL-c & LDL-c & VLDL-c \\
\hline Control (-ve) & $\begin{array}{l}85.691^{\mathrm{g}} \\
\pm 5.179\end{array}$ & $\begin{array}{l}38.681^{f} \\
\pm 4.552\end{array}$ & $\begin{array}{l}49.190^{a} \\
\pm 4.104\end{array}$ & $\begin{array}{l}28.765^{h} \\
\pm 0.619\end{array}$ & $\begin{array}{l}7.736^{f} \\
\pm 0.910\end{array}$ \\
\hline Contro & $\begin{array}{l}186.616^{a} \\
\pm 7.645\end{array}$ & $\begin{array}{l}90.791^{a} \\
\pm 5.151\end{array}$ & $\begin{array}{l}25.335^{\mathrm{e}} \\
\pm 2.542\end{array}$ & $\begin{array}{l}143.122^{a} \\
\pm 4.266\end{array}$ & $\begin{array}{l}18.158^{a} \\
\pm 1.030\end{array}$ \\
\hline $2.5 \% \quad N$ & $\begin{array}{l}162.666^{b c} \\
\pm 6.408\end{array}$ & $\begin{array}{l}74.166^{b c} \\
\pm 4.956\end{array}$ & $\begin{array}{l}32.000^{d} \\
\pm 3.485\end{array}$ & $\begin{array}{l}115.833^{c} \\
\pm 2.970\end{array}$ & $\begin{array}{l}14.833^{b c} \\
\pm 0.991\end{array}$ \\
\hline $5 \%$ N. s & $\begin{array}{l}148.643^{\mathrm{de}} \\
\pm 7.185\end{array}$ & $\begin{array}{l}68.095^{c} \\
\pm 5.780\end{array}$ & $\begin{array}{l}35.394^{\mathrm{cd}} \\
\pm 3.485\end{array}$ & $\begin{array}{l}99.630^{e} \\
\pm 3.155\end{array}$ & $\begin{array}{l}13.618^{c} \\
\pm 1.156\end{array}$ \\
\hline $10 \%$ N.sc & $\begin{array}{l}125.768^{f} \\
\pm 8.412\end{array}$ & $\begin{array}{l}53.732^{\mathrm{e}} \\
\pm 4.399\end{array}$ & $\begin{array}{l}42.105^{b} \\
\pm 4.522\end{array}$ & $\begin{array}{l}72.917^{g} \\
\pm 4.356\end{array}$ & $\begin{array}{l}10.746 \\
\pm 0.879\end{array}$ \\
\hline $\begin{array}{l}\text { Water extract of } N \text {. } \\
\text { sativa }(2.5 \%)\end{array}$ & $\begin{array}{l}168.455^{b} \\
\pm 7.704\end{array}$ & $\begin{array}{l}78.921^{b} \\
\pm 6.681\end{array}$ & $\begin{array}{l}31.052^{d} \\
\pm 3.246\end{array}$ & $\begin{array}{l}121.618^{b} \\
\pm 3.151\end{array}$ & $\begin{array}{l}15.784^{b} \\
\pm 1.336\end{array}$ \\
\hline $\begin{array}{l}\text { Water extract of } N \text {. } \\
\text { sativa }(5 \%)\end{array}$ & $\begin{array}{l}155.811^{c d} \\
\pm 6.302\end{array}$ & $\begin{array}{l}71.000^{c} \\
\pm 5.099\end{array}$ & $\begin{array}{l}32.666^{d} \\
\pm 3.669\end{array}$ & $\begin{array}{l}108.944^{d} \\
\pm 3.771\end{array}$ & $\begin{array}{l}14.200^{c} \\
\pm 1.019\end{array}$ \\
\hline $\begin{array}{l}\text { Water extract of } N \text {. } \\
\text { sativa }(\mathbf{1 0 \%})\end{array}$ & $\begin{array}{l}142.333^{\mathrm{e}} \\
\pm 4.179\end{array}$ & $\begin{array}{l}61.000^{d} \\
\pm 5.403\end{array}$ & $\begin{array}{l}38.833^{b c} \\
\pm 3.669\end{array}$ & $\begin{array}{l}91.300^{f} \\
\pm 1.532\end{array}$ & $\begin{array}{l}12.200^{d} \\
\pm 1.080\end{array}$ \\
\hline
\end{tabular}

Ch: Cholesterol TG: Triglycerides HDL-c: High density lipoprotein-cholesterol

LDL-c: Low density lipoprotein-cholesterol VLDL-c: Very low density lipoprotein-cholesterol

LSD: Least significant differences $(P<0.05) \quad$ Mean values in each column with same letters are not significantly different. 
The mean values of serum cholesterol, triglyceride's, LDL-c and VLDL-c decreased gradually with increasing the levels of Nigella sativa seeds or water extract, while HDL-c increased gradually.

Table (2) revealed that, the group of rats which suffer from hyperlipidemia and diabetes and fed on hyperlipidemic diet containing 10\% Nigella sativa seeds recorded significant decrease $\mathrm{p}<0.05$ in cholesterol, triglycerides, LDL-c and VLDL-c by about $32.605 \%, 40.817 \%, 49.052 \%$ and $40.819 \%$, respectively, while HDL-c increased by about $66.193 \%$, as compared to the positive control group. On the other hand, treating rats with the high concentration of water extract which prepared from $10 \%$ Nigella sativa recorded significant decrease $\mathrm{p}<0.05$ in cholesterol, triglycerides, LDL-c and VLDL-c by about $23.769 \%, 32.812 \%, 36.208 \%$ and $32.812 \%$, respectively, while HDL-c increased by about $53.278 \%$, as compared to the positive control group.

From these results it could be concluded that, Nigella sativa seeds or water extract prepared from this seeds improved the lipid profile in rats suffering from hyperlipidemia and diabetes. In this respect, the seeds of Nigella sativa plant have been used to promote health and fight disease for centuries especially in the Middle East and Southeast Asia. In South Asia, it is called Kalonji, its Arabic name is Habat-ul-Sauda and its English name is black cumin. This plant has been a great focus of research and has several traditional uses and consequently has been extensively studied for its chemical constituents and biological activities. A lot of animal studies have already been done to determine the various activities of Nigella sativa oil on different components of the metabolic syndrome for example blood sugar (Bamosa, 1997).

As an aromatic plant, black cumin (Nigella sativa) is widely grown in different parts of the world and the seeds of black cumin have been used to promote health for countries especially in the Middle East and Southeast Asia. Black cumin seeds have been widely used in traditional medicine as diuretic and antihypertensive (Zaoui et al., 2000), digestive and appetite stimulant (Gilani et al., 2004), antibacterial agents (Ferdous et al., 1992 and El-Kamali et al., 1998) antidiabetic (Meral et al., 2001), renal protective (Badary et al., 2000) and possessing antioxidant properties (Mansour et al., 2002).

Bahram et al., (2009) reported that, dietary black seed can favorably decrease serum lipid profile and lipid peroxidation levels in hyperlipidemic 
rabbits, therefore, it may be considered as a useful therapy for hyperlipidemia. Also Najmi et al., (2008) reported that, Nigella sativa oil is effective as an add-on therapy in patients with metabolic syndrome. Nigella sativa oil has a significant therapeutic activity in diabetic and dyslipidemic patients.

Muhammad and Muhammad (2007) reported that, Nigella sativa seeds in the diet have a favorable effect on lipid profile by lowering the triglyceride, total cholesterol and LDL cholesterol and increasing the HDL cholesterol in albino rats.

Nutritional supplementation can enhance the immune response in elderly humans by changing both the total amount and the type of dietary lipids (Hummell, 1993). N. sativa oil is rich in the $n-6$ PUFA a-linoleic acid (18:3n-6), the n-3 PUFA a-linolenic acid (18:3n-3), and a small amount of stearidonic acid (18:4n-3) (Laakso and Voutilainen 1996). The composition of the seeds reflects the recommended optimal dietary intake of n-3 and n-6 fatty acids, i.e., it has a ratio of n-3 to n-6 fatty acids of 1 to 4 or 5 (Yehuda and Carasso, 1993). Dietary supplementation with the N. sativa oil has found to improve the immune response of healthy elderly subjects, which is mediated by a change in the factors closely associated with $\mathrm{T}$ cell activation (Wu et al., 1999).

Indeed, in consistent with our results, the study of Zaoui et al., (2002) indicated that oral treatment with $N$. sativa oil, decreased serum cholesterol and TG levels by 15.5 and $22 \%$ in normal rats.

In another study, $N$. sativa oil administration to rats significantly decreased serum TC, LDL.C and TG and increased HDL.C (El-Dakhakhny et al., 2000).

Le et al. (2004) reported a significant decrease in plasma $\mathrm{TG}$ and an increase in HDL.C levels in black seed extract-oral treated rats, compared to the control group. Moreover, a significant reduction was observed in serum TC and LDL.C of patients with mild hypertension after 8 weeks of black seed extract oral administration (Dehkordi and Kamkhah, 2008).

The results of Bamosa et al. (2002) demonstrated a decrease in serum TC, LDL.C, HDL.C and TG during intraperitonial injection of thymoquinone in rats. Furthermore, the hypotriglyceridemic effect of nigellamines (that is black seed diterpene alkaloids) was reported in an in vitro study, equivalent to the hypolipidemic agent, clofibrate (Morikawa et al., 2004). 
The hypolipidemic effect of black seed does not seem to be due only to one component, but rather to the synergistic action of its different constituents, including TQ and nigellamine as mentioned above, soluble fiber (e.g. mucilage), sterols, flavonoids and high content of polyunsaturated fatty acids (PUFAs) (Ali and Blunden, 2003).

Mechanism of hypolipidemic action of TQ is not fully understood; however, decreased cholesterol synthesis, and more importantly, its antioxidant role have been proposed. Lipid lowering effects of dietary soluble fibers (Brown et al., 1999 and Talati et al., 2009) and sterols (Jones, 1999 and Moruisi et al., 2006) are probably related to decreased dietary cholesterol absorption, increased primary bile acid synthesis and its fecal losses. Flavonoids may act by making liver cells more efficient to remove LDL.C from blood. To do this, flavonoids increase LDL receptor densities in liver and by binding to apolipoprotein B (El-Beshbishy et al., 2006 and Weggemans and Trautwein, 2003).

Effect of Some Levels from Nigella Sativa as Seeds or Water Extract on kidney functions of Rats Suffering from Hyperlipidemia and Diabetes.

Table (3) presented the effect of different levels from (Nigella Sativa or water extract) on kidney functions $(\mathrm{mg} / \mathrm{dl}$ ), including (uric acid, urea nitrogen and creatinine) of rats suffering from hyperlipidemia and diabetes.

Data presented in table (3) observed that, values of uric acid, urea nitrogen and creatinine $(\mathrm{mg} / \mathrm{dl})$ for control positive group showed a significant increase $\mathrm{p}<0.05$, as compared to the control negative group.

Feeding groups which were suffering from hyperlipidemia and diabetes on hyperlipidemic diet containing different levels from (Nigella sativa) showed significant reduction in the mean values of uric acid and urea nitrogen and creatinine at $(\mathrm{p}<0.05)$, compared with the positive control group. The same trend was observed when used the different concentrations of water extracts prepared from $2.5 \%, 5 \%$ and $10 \%$ Nigella sativa. 


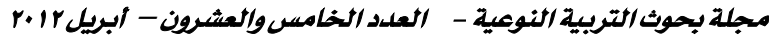

Table (3): Effect of Some Levels from Nigella Sativa as Seeds or Water Extract on Kidney Function of Rats Suffering from Hyperlipidemia and Diabetes.

\begin{tabular}{|c|c|c|c|}
\hline \multirow{2}{*}{$\begin{array}{l}\text { Parameters } \\
\text { Groups }\end{array}$} & \multicolumn{3}{|c|}{$\mathrm{mg} / \mathrm{dl}$} \\
\hline & Uric acid & Urea nitrogen & Creatinine \\
\hline Control (-ve) & $\begin{array}{r}1.642^{\mathrm{g}} \\
\pm 0.135\end{array}$ & $\begin{array}{l}28.120^{g} \\
\pm 2.536\end{array}$ & $\begin{array}{r}0.546^{\text {f }} \\
\pm 0.083\end{array}$ \\
\hline Control (+ve) & $\begin{array}{r}2.495^{\mathrm{a}} \\
\pm 0.119 \\
\end{array}$ & $\begin{array}{l}77.242^{\mathrm{a}} \\
\pm 4.778 \\
\end{array}$ & $\begin{array}{r}1.370^{\mathrm{a}} \\
\pm 0.101 \\
\end{array}$ \\
\hline $2.5 \%$ N. sativa seed & $\begin{array}{l}2.124^{b} \\
\pm 0.076\end{array}$ & $\begin{array}{l}68.641^{b} \\
\pm 2.574\end{array}$ & $\begin{array}{l}1.121^{b c} \\
\pm 0.081\end{array}$ \\
\hline $5 \%$ N. sativa seed & $\begin{array}{c}1.902^{\mathrm{d}} \\
\pm 0.088\end{array}$ & $\begin{array}{l}58.169^{d} \\
\pm 3.678\end{array}$ & $\begin{array}{c}0.933^{\mathrm{d}} \\
\pm 0.080\end{array}$ \\
\hline $10 \%$ N. sativa seed & $\begin{array}{c}1.756^{\mathrm{f}} \\
\pm 0.058\end{array}$ & $\begin{array}{l}42.625^{f} \\
\pm 1.896\end{array}$ & $\begin{array}{c}0.771^{\mathrm{e}} \\
\pm 0.072\end{array}$ \\
\hline $\begin{array}{l}\text { Water extract of } N \text {. } \\
\text { sativa }(2.5 \%)\end{array}$ & $\begin{array}{r}2.213^{b} \\
\pm 0.039 \\
\end{array}$ & $\begin{array}{l}71.000^{b} \\
\pm 3.162 \\
\end{array}$ & $\begin{array}{r}1.208^{b} \\
\pm 0.041 \\
\end{array}$ \\
\hline $\begin{array}{l}\text { Water extract of } N \text {. } \\
\text { sativa }(5 \%)\end{array}$ & $\begin{array}{r}2.012^{c} \\
\pm 0.100 \\
\end{array}$ & $\begin{array}{l}64.666^{c} \\
\pm 3.386 \\
\end{array}$ & $\begin{array}{r}1.050^{\mathrm{c}} \\
\pm 0.082 \\
\end{array}$ \\
\hline $\begin{array}{l}\text { Water extract of } N \text {. } \\
\text { sativa }(10 \%)\end{array}$ & $\begin{array}{r}1.889^{\mathrm{e}} \\
\pm 0.027\end{array}$ & $\begin{array}{l}50.333^{\mathrm{e}} \\
\pm 2.160\end{array}$ & $\begin{array}{r}0.897^{d} \\
\pm 0.033\end{array}$ \\
\hline
\end{tabular}

LSD: Least significant differences $(P<0.05) \quad$ Mean values in each column with same letters are not significantly different.

The mean values of serum uric acid, urea nitrogen and creatinine decreased gradually with increasing the levels of (Nigella sativa seeds and water extract of Nigella sativa). The lowest mean values of serum uric acid, urea nitrogen and creatinine recorded for the group which treated with the high level from Nigella sativa seeds $(10 \mathrm{~g} / 100 \mathrm{~g}$ diet $)$, followed by the group treated with water extract with the high concentration.

Serum uric acid, urea nitrogen and creatinine decreased by about $(29.619 \%$, 99.448 and $43.722 \%)$ and $(24.288 \%, 34.837 \%$ and $34.525 \%)$ in the groups which treated with $10 \%$ Nigella sativa seeds and water extract of Nigella sativa $(10 \%)$, respectively.

From these results it could be concluded that, Nigella sativa seeds or water extract prepared from this seeds improved kidney functions of rats suffering from hyperlipidemia and diabetes. 
$N$. sativa is an annual herbaceous plant that belongs to the family (Ranunculaceae) (Abedaziz and Kandeel, 2011 and Tajk et al., 2008). It contains carbohydrates, proteins, (AbdEl-Aleem and El-Deeb, 2006), linoleic, oleic and palmitic acid (Atta, 2003) and high concentrations of thymoquinone (TQ) and thymol (Al-Saleh et al., 2006).

Thymoquinone TQ inhibits nuclear factor-kappaB "NF-kB" (Sayed and Morcos, 2007). It may be a clinically valuable agent in the prevention of renal disease (Sayed-Ahmed and Nagi, 2007).In this respect, Ali, (2004) reported that, in gentamicine induced toxicity, treatment with N. sativa oil produced a dose-dependent amelioration of the biochemical and histological indices of nephrotoxicity, coincided with the increase in the scavenger defense system, including GSH concentration and the total anti-oxidant status in renal cortex.

Modern toxicological studies have demonstrated that crude extracts of the seeds and some of its active constituents (volatile oil, TQ) might have a protective effect against nephrotoxicity and hepatotoxicity induced by either disease or chemicals (Ali and Blunden 2003).

Effect of Some Levels from Nigella Sativa as Seeds or Water Extract on Serum Glucose and Liver Enzymes of Rats Suffering from Hyperlipidemia and Diabetes.

Finding in tables (4) presented the effect of three levels $(2.5 \%, 5 \%$ and $10 \%$ ) from Nigella Sativa seeds and the three concentrations from water extract prepared from $(25 \mathrm{~g}, 50 \mathrm{~g}$ and $100 \mathrm{~g}$ Nigella Sativa seeds / $1000 \mathrm{ml}$ water) on serum glucose and AST and ALT enzymes of rats suffering from hyperlipidemia and diabetes.

Feeding rats on hyperlipidemic diet and treated with $(150 \mathrm{mg}$ alloxan $/ \mathrm{kg}$ body weight) induced significant increase $\mathrm{p}<0.05$ in serum glucose and liver enzymes (AST \& ALT), as compared to healthy rats fed on basal diet.

Treating rats which were suffering from hyperlipidemia and hyperglycemia with different levels from Nigella Sativa seeds or water extract prepared from different levels from Nigella Sativa seeds improved the mean values of serum glucose, as compared to non-treated rats (negative control group). Serum glucose decreased gradually with increasing the levels of Nigella Sativa seeds, or increasing the concentration of water extract which prepared from Nigella Sativa seeds. The highest decrease in serum glucose recorded for the group which treated with diet containing $10 \%$ Nigella 


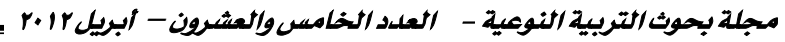

Sativa seeds followed by the group treated with water extract prepared from 10\% Nigella Sativa seeds. These treatments decreased the mean values of serum glucose by about $39.743 \%$ and $32.200 \%$, that that of the positive control group, respectively.

Table (4): Effect of Some Levels from Nigella Sativa as Seeds or Water Extract on Serum Glucose and Liver Enzymes of Rats Suffering from Hyperlipidemia and Diabetes.

\begin{tabular}{|c|c|c|c|}
\hline \multirow{2}{*}{ Groups } & \multirow{2}{*}{$\begin{array}{l}\text { Glucose } \\
(\mathrm{mg} / \mathrm{dl})\end{array}$} & \multicolumn{2}{|c|}{$\mathbf{U} / \mathbf{l}$} \\
\hline & & AST & ALT \\
\hline Control (-ve) & $\begin{array}{l}88.821^{\mathrm{g}} \\
\pm 3.893\end{array}$ & $\begin{array}{l}60.359^{f} \\
\pm 5.005\end{array}$ & $\begin{array}{l}26.884^{f} \\
\pm 2.783\end{array}$ \\
\hline Control (+ve) & $\begin{array}{c}215.833^{\mathrm{a}} \\
\pm 5.269\end{array}$ & $\begin{array}{c}106.450^{\mathrm{a}} \\
\pm 6.007\end{array}$ & $\begin{array}{l}61.399^{a} \\
\pm 3.653\end{array}$ \\
\hline $2.5 \% N_{.}$sativa seed & $\begin{array}{c}183.333^{\mathrm{c}} \\
\pm 2.582\end{array}$ & $\begin{array}{l}93.487^{b} \\
\pm 3.492\end{array}$ & $\begin{array}{l}54.033^{b} \\
\pm 3.495\end{array}$ \\
\hline $5 \%$ N. sativa seed & $\begin{array}{l}169.264^{\mathrm{e}} \\
\pm 3.687\end{array}$ & $\begin{array}{l}79.224^{d} \\
\pm 3.489\end{array}$ & $\begin{array}{l}41.116^{d} \\
\pm 2.695\end{array}$ \\
\hline $10 \%$ N. sativa seed & $\begin{array}{l}130.054 \\
\pm 4.058\end{array}$ & $\begin{array}{l}70.959^{\mathrm{e}} \\
\pm 3.220\end{array}$ & $\begin{array}{l}32.363^{\mathrm{e}} \\
\pm 2.587\end{array}$ \\
\hline $\begin{array}{l}\text { Water extract of } N . \\
\text { sativa }(2.5 \%)\end{array}$ & $\begin{array}{c}192.034^{b} \\
\pm 2.768\end{array}$ & $\begin{array}{l}97.333^{b} \\
\pm 3.266\end{array}$ & $\begin{array}{l}55.779^{b} \\
\pm 3.810\end{array}$ \\
\hline $\begin{array}{l}\text { Water extract of } N . \\
\text { sativa }(5 \%)\end{array}$ & $\begin{array}{c}178.500^{d} \\
\pm 3.209\end{array}$ & $\begin{array}{l}84.666^{c} \\
\pm 3.614\end{array}$ & $\begin{array}{l}45.500^{c} \\
\pm 1.760\end{array}$ \\
\hline $\begin{array}{l}\text { Water extract of } N . \\
\text { sativa }(10 \%)\end{array}$ & $\begin{array}{c}146.333^{f} \\
\pm 5.465 \\
\end{array}$ & $\begin{array}{l}74.500^{\mathrm{e}} \\
\pm 2.949 \\
\end{array}$ & $\begin{array}{l}38.333^{d} \\
\pm 1.861 \\
\end{array}$ \\
\hline
\end{tabular}

LSD: Least significant differences $(P<0.05) \quad$ Mean values in each column with same letters are not significantly different.

In this respect, numerous studies have found increased lipid peroxides or reactive oxygen species (ROS) and oxidative stress or both in different animal models of diabetes (Friedman et al., 2003). Oxidative stress refers to an imbalance between the intracellular production of free radicals and the cellular defense mechanism. Protein, lipids, and DNA are sensitive target of ROS. An excess availability of free radicals accompanied by a reduction in the capacity of the natural antioxidant systems leads to cellular dysfunction and death (Albers and Beal 2000). Free radical-induced DNA damage has been shown to be increased in embryos from diabetic rats (Viana et al., 1996). 
There has been increasing interest regarding the role and use of natural antioxidants as a means of preventing oxidative damage in diabetes due to high oxidative stress (Pritchard et al., 1986).

The black seed, Nigella sativa is known to contain $>30 \%$ of fixed oil and $0 / 4-0 / 45 \% \mathrm{wt}$. /wt. of volatile oil. The volatile oil is known to contain 18.4$24 \%$ thymoquinone (TQ) and $46 \%$ of monoterpenes such as p-cymene and a-piene (EL-Tahir et al., 1993).

Ali and Blunden (2003) reported that, the basis of the beneficial effect of Nigella sativa in diabetes might be its antioxidant property.

The mean values of serum AST \& ALT increased significantly $p<0.05$ in the positive control croup, as compared to the negative control group. Feeding rats on hyperlipidemic diet and treated with alloxan increased serum AST \& ALT enzymes by about $76.361 \%$ and $128.384 \%$, than that of the negative control group, respectively.

The results in this table indicated that, all treated rats which were suffering from hyperlipidemia and hyperglycemia with Nigella Sativa seeds or water extract prepared from different concentrations from Nigella Sativa seeds, decreased both AST and ALT enzymes significantly, as compared to the positive control group.

Treating group which suffering from hyperlipidemia and hyperglycemia with hyperlipidemic diet containing 10\% Nigella Sativa seeds recorded the highest decrease in both AST and ALT enzymes, as compared to other treated groups, followed by the group treated with water extract prepared from $10 \%$ Nigella Sativa seeds.

In CCl4-induced toxicity, Nigella Sativa oil protected against hepatotoxicity coinciding with improvement in serum lipid profile (El-Dakhakhny et al., 2000 and Nagi et al., 1999), decreasing the elevated liver enzyme levels, and increasing the reduced anti-oxidant enzyme levels (Kanter et al., 2003). Moreover, treatment with $\mathrm{N}$. sativa oil prevented CCl4-induced liver fibrosis in rabbits with improvement of the anti-oxidant status (Turkdogan et al., 2001).

Kanter et al., (2005) reported that, Nigella sativa has hepato-protective effect. It protects liver from many toxic metals 


\section{REFERENCES:}

Abd El-Aleem, I.M. and El-Deeb, A.E. (2006). Implication of different heating periods on some chemical compounds and nutritional value of Nigella sativa L. J. Biol. Chem. Environ. Sci., 1(4): 735-750.

Abedaziz, I. and Kandeel, M. (2011). The protective effects of Nigella sativa oil and Allium sativum Extract on Amikacin Nephrotoxicity. Int. J. Phamacol., 7(6): 697-703.

Akram, K.M. (1999). Chemical composition and medicinal properties of Nigella sativa Linn. Inflammopharmacol. 7 (1): 15-35.

Albers, D.S. and Beal, M.F. (2000). Mitochondrial dysfunction and oxidative stress in aging and neurodegenerative disease. J. Neural Transm.; 59: $133-154$.

Ali, B.H. (2004). The effect of Nigella sativa oil on gentamicin nephrotoxicity in rats. Am. J. Chin. Med.; 32:49-55.

Ali, B.H. and Blunden, G. (2003). Pharmacological and toxicological properties of Nigella sativa. Phytother. Res. 17 (4): 299-305.

Allain, C.C.; Poon, L. S.; Chan, C.S.; Richmond, W. and Fu, P.C. (1974). Enzymatic determination of total serum cholesterol. Clin. Chem., 20(4):470-475.

Al-Saleh, I.A.; Billedo, G. and El-Doush, I.I. (2006). Levels of selenium, DL- $\alpha$ tocopherol, DL- $\gamma$-tocopherol, all-trans-retinol thymoquinone and thymol in different brands of Nigella sativa seeds. J. Food Compost. Anal., 19(2-3): 167-175.

Atta, M .B. (2003). Some characteristics of nigella (Nigella sativa L.) seed cultivated in Egypt and its lipid profile. Food Chem., 83(1): 63-68.

Badary, O. A.; Abdel-Naim, A. B.; Abdel-Wahab, M. H. and Hamada, F. M. (2000). The influence of thymoquinone on doxorubicin-induced hyperlipidemic nephropathy in rats. Toxicol. 143: 19-226.

Bahram, P. G.; Vahideh, E. A.; Maryam, R. and Abolfazl, G. (2009). Effect of dietary supplementation with Nigella sativa L. on serum lipid profile, lipid peroxidation and antioxidant defense system in hyperlipidemic rabbits. Journal of Medicinal Plants Research 3(10): 815-821.

Bamosa A. O. (1997). Effect of oral ingestion of Nigella sativa seeds in some blood parameters. Saudi Pharm. J.; 5: 126-129.

Bamosa, A.O.; Ali, B.A. and al-Hawsawi, Z.A. (2002). The effect of thymoquinone on blood lipids in rats. Indian. J. Physiol. Pharmacol. 46 (2): 195-201.

Brown, L.; Rosner, B.; Willett, W.W. and Sacks, F.M. (1999). Cholesterollowering effects of dietary fiber: a meta-analysis. Am. J. Clin. Nutr. 69 (1): $30-42$. 
Buko, V.; Lukivskaya, O.; Nikitin, V.; Tarasov, Y.; Zarodnik, L.; Borodassky, A.; Gorenshetin, B.; Janz, B. and Gundermann, K.J. (1996): Hepatic and pancreatic effects of polyenoylphtidyl choline in rats with alloxan induced diabetes. Cell Biochem. Funct; 14(2): 131-137.

Burits, M. and Bucar, F. (2000). Antioxidant activity of Nigella sativa essential oil. Phytother. Res. 14 (5): 323-8.

Cara, L.; Borel, P.; Armand, M.; Senfit, M.; Riottot, M.; Lairon, D. and Ferezou, J. (1991): Effects of increasing levels of raw or defatted wheat germ on liver. Feces and plasma lipids and lipoproteins in the rat. NutrRes. Elmsford, N.Y.: Pergamon Press; 11 (8): 907-916.

Chapman, D.G.; Castilla, R. and Campbell, J.A. (1959). Evaluation of protein in food. Determination of protein and food efficiency ratio. Can. J. Biochem. and Physil., 37: 679-686.

Dattner, A.M. (2003). From medical herbalism to phytotherapy in dermatology: back to the future. Dermatol Ther.; 16: 106-113.

Dehkordi, F.R. and Kamkhah, A.F. (2008). Antihypertensive effect of Nigella sativa seed extract in patients with mild hypertension. Fundam. Clin. Pharmacol. 22 (4): 447-52.

El-Beshbishy, H.A.; Singab, A.N.B.; Sinkkonen, J. and Pihlaja, K. (2006). Hypolipidemic and antioxidant effects of Morus alba L. (Egyptian mulberry) root bark fractions supplementation in cholesterol-fed rats. Life Sci.; 78: $2724-2733$.

El-Dakhakhny, M.; Mady, N.I. and Halim, M.A. (2000). Nigella sativa L. oil protects against induced hepatotoxicity and improves serum lipid profile in rats. Arzneimittelforschung 2000; 50:832-6.

El-Din, K.; El-Tahir, H. and Bakeet, D.M. (2006). The black seed (Nigella sativa Linnaeus) - a mine for multi cures: A plea for urgent clinical evaluation of its volatile oil. JTU. Med. Sci. 1: 1-19.

El-Kamali, H. H.; Ahmad, A. H.; Mohammad, A. S.; Yahia, A. A. M.; ElTayeb, I. and Ali, A. A. (1998). Antibacterial properties of essential oils from Nigella sativa seeds etc. Fitoterapia, 69:77- 78.

EL-Tahir, K.E.; Ashour, M.M. and Al-Harbi, M.M. (1993). The respiratory effects of the volatile oil of the black seed (Nigella sativa) in guineapigs: elucidation of the mechanism(s) of action. Gen. Pharmacol.; 24: 1115-1122.

Farida, M.; Al-Awadi, F.M. and Gumaa, K.A. (1987). Studies on the activity of individual plants of an antidiabetic plant mixture. Acta Diabetol. Lat., 24, $37-41$. 
مجلة بحوث التربية النوعية - العلد الخامس والعشرون - أبريل r r r م

Ferdous, A. J.; Islam, S. N.; Ahsan, M.; Hasan, C. M. and Ahmad, Z. U. (1992). In vitro antibacterial activity of the volatile oil of Nigella sativa seeds against multiple drug-resistant isolates of Shigella species and isolates of Vibrio cholerae and Escherichia coli. Phytotherpy Res. 6:137140.

Fong, H.H. (2002). Integration of herbal medicine into modern medical practices: issues and prospects. Integr. Cancer Ther.; 1:287- 293.

Fossati, P. and Prenape, L. (1982). Serum triglycerides determined colorimetrically with enzyme that produce hydrogen peroxide. Clin. Chem., 28:2077-2080.

Fossati, P.; Prencipe, L. and Berti, G. (1980). Uric acid measurements with enzymatic colorimetric method. Clin. Chem., 26:227-273.

Friedman, J.; Peleg, E.; Kagan, T.; Shnizer, S. and Rosenthal, T. (2003). Oxidative stress in hypertensive, diabetic, and diabetic hypertensive rats. Am. J. Hypertens.; 16: 1049-1052.

Friedwald, W.T.; Levy, R.I. and Fredriclsor, D.S. (1972). Estimation of the concentration of low density lipoprotein cholesterol in plasma without use of the preparative ultracentrifuge. Clin. Chem., 18:499-502.

Gilani, A. H.; Jabeen, Q. and Khan, M. A. U. (2004). A Review of Medicinal Uses and Pharmacological Activities of Nigella sativa. Pakistan J. Biol. Sci. 7:441-451.

Hajhashemi, V.; Ghannadi, A. and Jafarabadi, H. (2004). Black cumin seed essential oil, as a potent analgesic and antiinflammatory drug. Phytother. Res. 18(3): 195-199.

Henry, R.J. (1974). Creatinine measurements with colorimetric method. Clin Chem., principles and technics. $2^{\text {nd }}$ ed., Harper\& Row publishers, p:525.

Hummell, D.S. (1993). Dietary lipids and immune function. Prog. Food Nutr. Sci.;17:287-329.

Hunt, L.M.; Arar, N.H. and Akana, L.L. (2000). Herbs, prayer, and insulin: Use of medical and alternative treatments by a group of Mexican-American diabetic patients. J. Fam. Pract.; 49: 216-223.

Jaffar, A.R.; Babb, J.; Movahed, A. (2004). Optimal management of hyperlipidemia in primary prevention of cardiovascular disease. Int. J. Cardiol. 97 (3): 355-366.

Jones, P.J. (1999). Cholesterol-lowering action of plant sterols. Curr. Atheroscler. Rep. 1 (3): 230-235.

Kanter, M.; Coskun, O. and Gurel, A. (2005). Effect of black cumin (Nigella sativa) on cadmium-induced oxidative stress in the blood of rats. Biol. Trace Elem. Res., 107(3): 277-287. 
Kanter, M.; Meral, I.; Dede, S.; Gunduz, H.; Cemek, M. and Ozbek, H. (2003). Effects of Nigella sativa L. and Urtica dioica L. on lipid peroxidation, antioxidant enzyme systems and some liver enzymes in CCl4-treated rats. J. Vet. Med. A Physiol. Pathol. Clin. Med. 2003;50:264-8.

Laakso, P. and Voutilainen, P. (1996). Analysis of triacylglycerols by silver-ion high-performance liquid chromatography-atmospheric pressure chemical ionization mass spectrometry. Lipids ;31:1311-22.

Le, P.M.; Benhaddou-Andaloussi, A.; Elimadi, A.; Settaf, A.; Cherrah, Y. and Haddad, P.S. (2004). The petroleum ether extract of Nigella sativa exerts lipid-lowering and insulin-sensitizing actions in the rat. $J$. Ethnopharmacol., 94: 251-9.

Lopes-Virella, M.F.; Stone, S.; Ellis, S. and Collwell, J.A. (1977). Cholesterol determination in high-density lipoproteins separated by three different methods. Clin. Chem., 23(5):882-886.

Mansour, M. A.; Nagi, M. N.; El-Khatib, A. S. and Al-Bekairi, A. M. (2002). Effects of thymoquinone on antioxidant enzyme activities, lipid peroxidation and DT- diaphorase in different tissues of mice: a possible mechanism of action. Cell Biochem. Funct. 20:143-151.

Meral, I.; Yener, Z.; Kahraman, T. and Mert, N. (2001). Effect of Nigella sativa on glucose concentration, lipid peroxidation, anti-oxidant defense system and liver damage in experimentally-induced diabetic rabbits. J. Vet. Med. A. Physiol. Pathol. Clin. Med. 48:593-599.

Morikawa, T.; Xu, F.; Ninomiya, K.; Matsuda, H. and Yoshikawa, M. (2004). Nigellamines A3, A4, A5, and C, new dolabellane-type diterpene alkaloids, with lipid metabolism-promoting activities from the Egyptian medicinal food black cumin. Chem. Pharm. Bull. 52 (4): 494-7.

Moruisi, K.G.; Oosthuizen, W.; Opperman, A.M. (2006). Phytosterols/stanols lower cholesterol concentrations in familial hypercholesterolemic subjects: a systematic review with meta-analyses. J. Am. Coll. Nutr. 25 (1): 41-8.

Muhammad, A.B. and Muhammad, T (2007). Effect of Nigella sativa on lipid profile in diabetic rats. Gomal Journal of Medical Sciences Jan-June, 5 (1): 28-31.

Nagi, M.N.; Alam, K.; Badary, O.A.; al-Shabanah, O.A.; al-Sawaf, H.A. and al-Bekairi, A.M. (1999). Thymoquinone protects against carbon tetrachloride hepatotoxicity in mice via an antioxidant mechanism. Biochem Mol Biol Int 1999;47:153-9.

Najmi, A.; Haque, S.F.; Naseeruddin, M. and Khan, R.A. (2008). Effect of Nigella Sativa oil on various clinical and biochemical parameters of metabolic syndrome. Int. J. Diabetes \& Metabolism, 16: 85-87. 
مجلة بحوث التربية النوعية - العلدد الخامسوالعشرون - أبريل r ا.r م

Padhye, S.; Banerjee, S.; Ahmad, A.; Mohammad, R. and Sarkar, F.H. (2008). From here to eternity - the secret of Pharaohs: Therapeutic potential of black cumin seeds and beyond. Cancer. Ther. 6 (b): 495-510.

Patton, C.J. and Crouch, S.R. (1977): Enzymatic colorimetric method to determination urea in serum. Anal. Chem., 49: 464.

Prasad, K. (2005). Hypocholesterolemic and antiatherosclerotic effect of flax lignan complex isolated from flaxseed. Atherosclerosis. 179 (2): 269275.

Pritchard, K.A.; Patel, S.T.; Karpen, C.W.; Newman, H.A. and Panganamala, R.V. (1986). Triglyceride-lowering effect of dietary vitamin $E$ in streptozotocin-induced diabetic rats. Increased lipoprotein lipase activity in livers of diabetic rats fed high dietary vitamin E. Diabetes; 35 : 278281.

Ramadan, M.F. (2007). Nutritional value, functional properties and nutraceutical applications of black cumin (Nigella sativa L.): an overview. Int. J. Food. Sci. Tech. 42 (10): 1208-1218.

Reeves, P.G.; Nielsen, F.H. and Fahmy, G.C.(1993): AIN-93 purified diets for laboratory rodents: final report of the American Institute of Nutrition ad hoc writing committee on the reformulation of the AIN-76A rodent diet. J. Nutr.; 123 (11): 1939-1951.

Reitman, S. and Frankel, S. (1957). A colorimetric method for the determination of serum oxaloacetic and glutamic pyruvic transaminases. Am. J. Clin. Pathol., 28,56.

Sacks, D.B. (1997). Implications of the revised criteria for diagnosis and classification of diabetes mellitus. Clin. Chem., 43, 2230-2233.

Sayed, A.A. and Morcos, M. (2007). Thymoquinone decreases AGE-induced NFkappaB activation in proximal tubular epithelial cells. Phytother. Res., 21(9): 898-899.

Sayed-Ahmed, M.M. and Nagi, M.N. (2007). Thymoquinone supplementation prevents the development of gentamicin-induced acute renal toxicity in rats. Clin. Exp. Pharmacol. Physiol., 34(5-6): 399-405.

Steel, R.G. \& Torri, J.H. (1980). Principle and procedures of statistical biometrical approach. 2nd edn. Pbi. Mc Grew Hill Book Company; New York; U.S.A.

Tajk, H.; Jalala, F.; Sh, S. and Javadi, S.h. (2008). Comparison of Antibacterial Activities of Natural Urmia Honey and Penicillin Derivatives. An In vitro Study. J. Anim. Vet. Adv., 7(9): 1097-1100.

Talati, R.; Baker, W.L.; Pabilonia, M.S.; White, C.M. and Coleman, C.I. (2009). The effects of barley-derived soluble fiber on serum lipids. Ann. Fam. Med. 7 (2): 157-163. 
Tinder, P. (1959). Determination of blood glucose level. J. Clin. Path., 22: 246.

Turkdogan, M.K.; Agaoglu, Z.; Yener, Z.; Sekeroglu, R.; Akkan, H.A. and Avci, M.E. (2001). The role of antioxidant vitamins (C and E), selenium and Nigella sativa in the prevention of liver fibrosis and cirrhosis in rabbits: newhopes. Dtsch Tierarztl. Wochenschr; 108:71-3.

Viana, M.; Herrera, E. and Bonet, B. (1996). Teratogenic effects of diabetes mellitus in the rat. Prevention with vitamin E. Diabetologia; 39: 10411046.

Weggemans, R.M. and Trautwein, E.A. (2003). Relation between soyassociated isoflavones and LDL and HDL cholesterol concentrations in humans: a Meta analyses. Eur. J. Clin. Nutr. 57 (8): 940-946.

Wu, D.; Meydani, M.; Leka, L.S.; Nightingale, Z.; Handelman, G.J. and Blumberg, J.B. (1999). Effect of dietary supplementation with black currant seed oil on the immune response of healthy elderly subjects. $\mathrm{Am}$. J. Clin. Nutr.;70:536-43.

Yehuda, S. and Carasso, R.L. (1993). Modulation of learning, pain thresholds, and thermoregulation in the rat by preparations of free purified alphalinolenic and linoleic acids: determination of the optimal omega 3-toomega 6 ratio. Proc Natl Acad Sci U S A 1993; 90:10345 - 9.

Zaoui, A.; Cherrah, Y.; Alaoui, K.; Mahassine, N.; Amarouch, H. and Hassar, M. (2002). Effects of Nigella sativa fixed oil on blood homeostasis in rat. J. Ethnopharmacol. 79 (1): 23-6. 


\title{
تأثير بعض المستويات هن حبة البركة كبذور أو المستخلص المائى على الفئران التى تعانى هن ارتفاع هستوى دهون الدم والسكر
}

\author{
منى مسعود السيد \\ قسم التغذية وعلوم الأطعمة - كلية الاقتصاد المنزلى - جامعة حلوان موديل
}

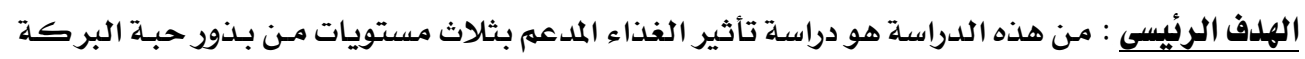

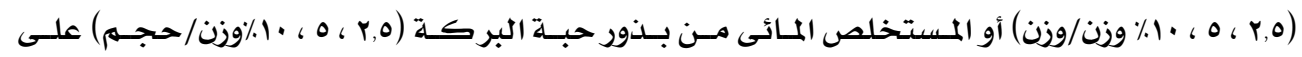

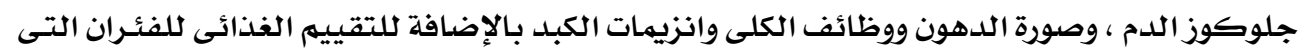

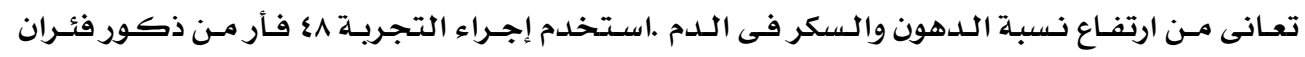

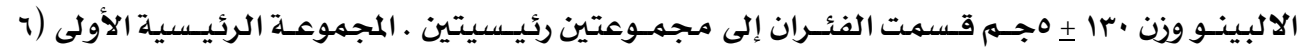

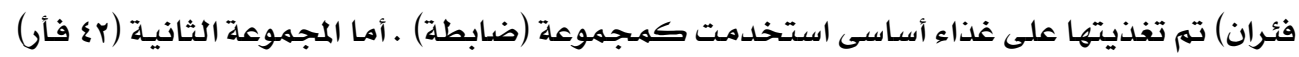

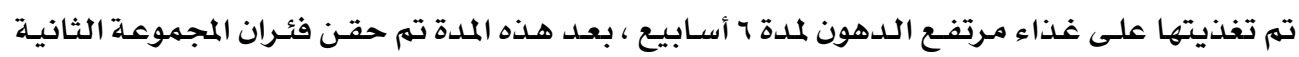

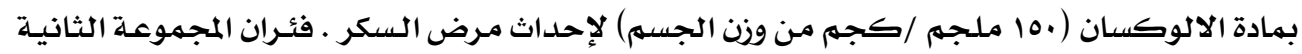

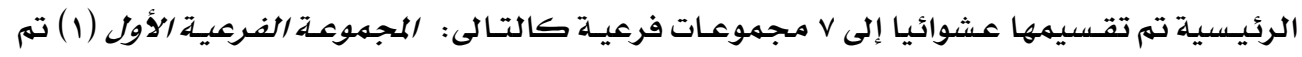

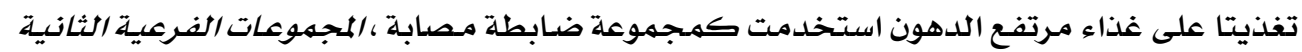

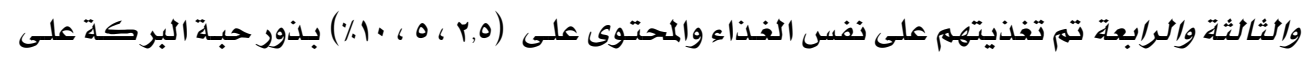

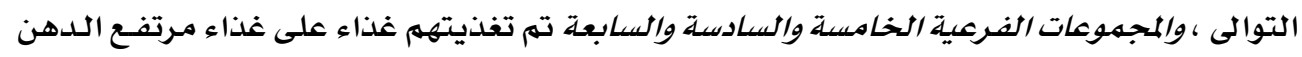

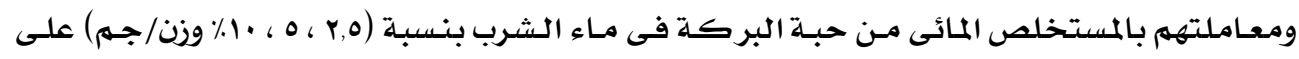

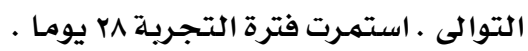

أشـارت النتائج إلى أن الإصـابة بارتفـاع مستوى دهـون اللدم والجلوكـوز أدى إلى زيـادة معـدل

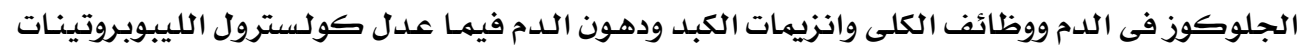

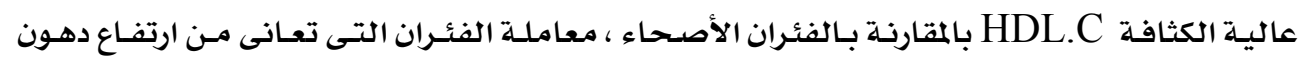

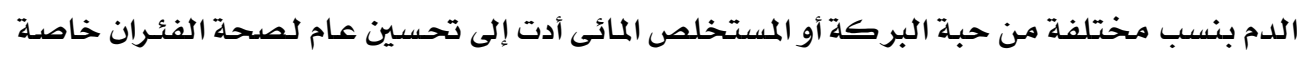

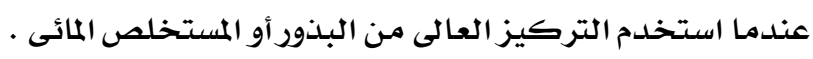

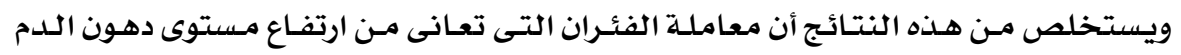

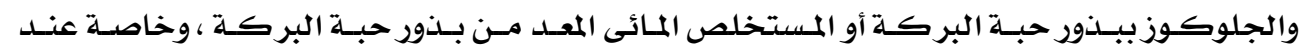

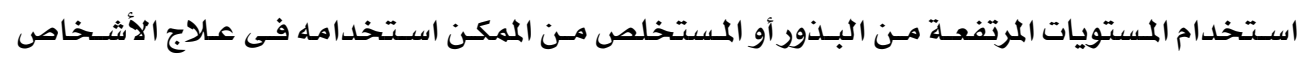

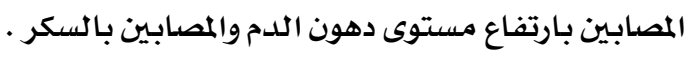

الكلمات المفتاحية :

ارتفـاع دهون الدم - السكر - فئـران - حبـة البر كـة - جلوكوز - صدورة الدهون - وظائف

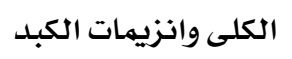

